\title{
BRPKM
}

Buletin Riset Psikologi dan Kesehatan Mental

http://e-journal.unair.ac.id/index.php/BRPKM

e-ISSN: 2776-1851

ARTIKEL PENELITIAN

\section{Pengaruh Quality of Work Life terhadap Work Engagement dengan Workplace Happiness sebagai Variabel Mediator pada Pekerja Work from office di Masa Pandemi COVID-19}

\author{
CHANSA VISYAHRA NUGRAHA \& FENDY SUHARIADI* \\ Fakultas Psikologi Universitas Airlangga
}

\begin{abstract}
ABSTRAK
Penelitian ini bertujuan untuk mengetahui pengaruh kualitas kehidupan kerja terhadap keterikatan kerja melalui kebahagiaan di tempat kerja sebagai variabel mediator. Penelitian ini melibatkan 143 pekerja yang bekerja dari kantor di masa pandemi COVID-19. Instrumen pengumpulan data berupa kuesioner berjumlah 50 butir aitem, dan analisis data dilakukan melalui uji bootstrapped mediation regression dengan bantuan perangkat Jamovi 1.1.7.0 for Mac OS. Hasil analisis data menunjukkan bahwa kualitas kehidupan kerja berpengaruh secara langsung terhadap keterikatan kerja dengan proporsi yang lebih besar apabila efek tersebut dimediasi oleh kebahagiaan di tempat kerja. Kebahagiaan di tempat kerja juga diketahui dapat menjelaskan sekitar 73,9\% dari efek total. Hasil dalam penelitian ini menunjukkan bahwa kebahagiaan di tempat kerja memiliki efek mediasi yang signifikan, dan berperan secara parsial.
\end{abstract}

Kata kunci: covid-19, kebahagiaan di tempat kerja, keterikatan kerja, kualitas kehidupan kerja

\begin{abstract}
This study aims to determine the effect of the quality of work life on work engagement through workplace happiness as a mediator variable. The research involved 143 workers who worked from office during the COVID-19 pandemic. The data collection instrument uses a questionnaire totaling 50 items, and data was analyzed through bootstrapped mediation regression method using Jamovi 1.1.7.0 for Mac OS software. The results of data analysis show that quality of work life has a direct effect on work engagement with a greater proportion if this effect is mediated by workplace happiness. Workplace happiness is also known to explain about $73.9 \%$ of the total effect. The results revealed that workplace happiness plays a significant mediation role in the effect of the quality of work life on work engagement, and classified as a partial mediation.
\end{abstract}

Keywords: covid-19, quality of work life, work engagement, workplace happiness

Buletin Penelitian Psikologi dan Kesehatan Mental (BRPKM), 2021, Vol. 1(1), 532-540

*Alamat korespondensi: Fakultas Psikologi Universitas Airlangga, Kampus B Universitas Airlangga Jalan Airlangga 4-6 Surabaya 60286. Surel: fendy.suhariadi@psikologi.unair.ac.id 


\section{PENDAHULUAN}

Fenomena Coronavirus Disease-19 (COVID-19) yang disebabkan oleh virus SARS-CoV-2 sedang mengancam dunia sejak awal tahun 2020. Kasus yang tercatat di setiap negara di seluruh dunia masih menunjukkan peningkatan di setiap harinya menjadikan COVID-19 sebagai pandemi global oleh World Health Organization (WHO) sejak pertengahan Maret 2020. Upaya yang diterapkan guna mengurangi penyebaran virus menyebabkan krisis di berbagai sektor, salah satunya pada sektor bisnis dan industri, sehingga COVID-19 telah dianggap sebagai ancaman terhadap keadaan ekonomi dalam skala Internasional (Kniffin, 2020).Selain itu, pembatasan pada sektor bisnis dan industri menghasilkan beragam tantangan baru bagi organisasi maupun pekerja, salah satunya melalui perubahan praktek kerja normal menjadi rutinitas kerja secara online atau virtual. Perubahan-perubahan dalam kondisi pandemi ini menuntut perusahaan untuk dapat memberikan perhatian lebih dalam mencapai work engagement yang dirasakan oleh pekerja, mengingat tenaga kerja sebagai sumber daya manusia merupakan faktor yang sentral dan esensial dalam organisasi (Kumar \& Kapoor, 2020).

Berdasarkan tinjauan literatur pada penelitian sebelumnya, diketahui bahwa work engagement yang dimiliki pekerja merupakan titik fokus organisasi karena dianggap sebagai prediktor terbaik dalam menjelaskan hasil yang diperoleh oleh pekerja, tim, dan organisasi (Bakker \& Albrecht, 2018); meningkatkan produktivitas dan keuntungan organisasi, financial performance, kepuasan pelanggan, dan dapat menyumbangkan sebesar 112\% pengembalian saham (Harter, dkk., 2002; Xanthopoulou, dkk., 2009; Zhao \& Sun, 2010). Namun, dalam kenyataan aktual di lapangan menunjukkan rendahnya angka pekerja yang terikat dengan pekerjaanya, yaitu hanya sebesar $31 \%$ pekerja di seluruh dunia yang memiliki keterikatan kerja tinggi dan hanya 8\% pekerja Indonesia yang terikat secara penuh dengan pekerjaannya, serta para pekerja mengalami penurunan tingat keterikatan kerja sebesar $28 \%$ akibat pandemi COVID-19 dengan lebih dari setengah dipicu munculnya perasaan cemas saat kembali ke kantor (Marajohan, 2016; Coronavirus Knowledge Portal, 2020; Harter, 2020). Padahal, pekerja yang memiliki keterikatan kerja tinggi akan menunjukkan tingkah laku yang berorientasi pada tujuan, sedangkan pekerja yang memiliki keterikatan kerja yang rendah akan menunjukkan sikap kurang peduli terhadap pekerjaan dan cenderung menggunakan waktu kerja dengan melakukan hal-hal yang kurang produktif dan akan ya mengarahkan pada hilangnya keuntungan perusahaan karena performa kerja yang menurun (Pri \& Zamralita, 2017; Muslim, dkk., 2018).

Dalam hubungannya dengan setting situasi pandemi COVID-19, dinyatakan bahwa work engagement memiliki keterkaitan dalam peningkatan produktivitas, serta peningkatan komitmen pekerja pada organisasi dan tetap mendorong pekerja untuk merasa termotivasi selama masa krisis juga sulit (Chanana \& Sangeeta, 2020). Selain itu, diketahui bahwa tingkat keterikatan kerja akan berpengaruh terhadap performa organisasi, dimana keterikatan kerja menunjukkan hubungan secara langsung dengan produktivitas, absenteeism, tingkat turnover, operational efficiency, juga peningkatan earningsper-share (EPS) perusahaan (Rotenberg, 2021). Hal ini juga didukung oleh hasil penelitian sebelumnya yang menyatakan bahwa upaya dalam memelihara work engagement dianggap sebagai tantangan besar bagi organisasi selama masa pandemi COVID-19, karena diketahui dapat mendorong pekerja untuk menampilkan performa terbaik dalam pekerjaannya, mengarahkan pada peningkatan produktivitas, juga memelihara kesejahteraan (well-being) para pekerja (Fadini, 2021). 
Dalam menjelaskan work engagement, kualitas kehidupan kerja dianggap memiliki pengaruh yang signifikan dalam proses penciptaan dan penguatan tingkat keterikatan kerja (Nurendra \& Purnamasari, 2017; Avianto, dkk., 2019). Keterikatan kerja diketahui termasuk salah satu aspek yang dipengaruhi dan tidak dapat terlepas oleh konstruk kualitas kehidupan kerja. Konstruk ini dianggap sebagai salah satu faktor yang paling penting bagi perusahaan dalam mencapai tujuan memperoleh efektivitas organisasi, karena peningkatan engagement pada level individual diketahui dapat dicapai melalui peningkatan penerapan quality of work life (Sahni, 2019). Penerapan kualitas kehidupan kerja juga diidentifikasi sebagai hal yang penting dalam memelihara kebahagiaan yang dirasakan oleh pekerja (Butt, dkk., 2019).Pekerja yang merasa bahagia diketahui lebih loyal dan cenderung bekerja lebih keras, sehingga akan menghasilkan performa kerja yang lebih baik (Alexander, 2019).Hal ini secara langsung menjadi mekanisme kausal yang menyebabkan berbagai keadaan positif di tempat kerja dan mengarahkan pekerja untuk dapat lebih terikat dengan pekerjaannya, selaras dengan penelitian sebelumnya (Hempfling, 2015; Claypool, 2017; Alexander, 2019).

\section{Work Engagement}

Work engagement merupakan sesuatu yang positif, keadaan pikiran yang berhubungan dengan kesejahteraan pekerjaan dan pemenuhan diri dengan karakteristik energi yang tinggi dan teridentifikasi kuat dalam suatu pekerjaan, yang ditandai dengan adanya perasaan semangat (vigour), dedikasi (dedication), dan penghayatan (absorption) (Schaufeli \& Bakker, 2004).

\section{Quality of Work Life}

Quality of work life merupakan istilah untuk menjelaskan prinsip-prinsip lingkungan dan manusia, juga mengacu pada sebuah strategi yang dilakukan oleh organisasi untuk meningkatkan kondisi kerja dan keuntungan organisasi maupun para pekerja (Walton, 1980).

\section{Workplace Happiness}

Workplace happiness merupakan perasaan bahagia dalam pekerjaan itu sendiri, dalam karakteristik pekerjaan, serta dalam keseluruhan organisasi, dan mengacu pada penilaian yang menyenangkan (sikap positif) atau pengalaman menyenangkan (perasaan positif, mood, emosi) di tempat kerja (Fisher, 2010). Berdasarkan pemaparan teori dan keterkaitan antar teori diatas, maka hipotesis pada penelitian ini adalah sebagai berikut:

$\mathrm{H}_{1}$ : Terdapat pengaruh quality of work life terhadap work engagement pada pekerja yang bekerja dari kantor (work from office) di masa pandemi COVID-19.

$\mathrm{H}_{2}$ : $\quad$ Terdapat pengaruh quality of work life terhadap workplace happiness pada pekerja yang bekerja dari kantor (work from office) di masa pandemi COVID-19.

$\mathrm{H}_{3}$ : $\quad$ Terdapat pengaruh workplace happiness terhadap work engagement pada pekerja yang bekerja dari kantor (work from office) di masa pandemi COVID-19.

$\mathrm{H}_{4}$ : $\quad$ Terdapat efek mediasi pada pengaruh quality of work life terhadap work engagement melalui workplace happiness pada pekerja yang bekerja dari kantor (work from office) di masa pandemi COVID-19 


\section{METODE}

\section{Desain Penelitian}

Penelitian ini merupakan tipe penelitian dengan pendekatan kuantitatif. Metode yang digunakan dalam penelitian ini adalah metode survei dengan analisis eksplanatif kuantitatif. Metode survei merupakan metode penelitian dengan menggunakan kuesioner yang berisi alat ukur sebagai instrumen utama dalam proses pengumpulan data, sedangkan metode eksplanatif kuantitatif merupakan penelitian yang bertujuan untuk menjelaskan hubungan antara satu variabel dengan variabel yang lain melalui pengujian hipotesis (Djamba \& Neuman, 2002; Bungin, 2011).

\section{Partisipan}

Dalam penelitian ini, target populasi partisipan adalah pekerja pada sebuah perusahaan, instansi, dan organisasi serta sedang bekerja dari kantor (work from office) selama masa pandemi COVID-19. Pengambilan sampel dalam penelitian ini menggunakan teknik non-probability sampling dengan metode purposive serta snowball sampling.

Peneliti melakukan perencanaan dalam jumlah sampel yang dibutuhkan dengan metode Monte Carlo Simulation, karena dalam Schoemann, dkk. (2017) diketahui bahwa analisis Monte Carlo merupakan metode yang sesuai untuk menilai kekuatan serta ukuran sampel dalam model mediasi. Berdasarkan acuan dalam Schoemann, dkk. (2017), maka hasil penelitian diasumsikan untuk memiliki effect size yang cenderung kecil hingga menengah; power $(1-\beta)$ sebesar $80 \%$; alpha $(\alpha)$ atau probabilitas terjadinya kesalahan tipe 1 (false positive) sebesar 0.05; serta koefisien korelasi (effect size) sebesar 0,2 untuk X-Y, sebesar 0,4 untuk X-M, dan sebesar 0,3 untuk variabel M-Y. Berdasarkan hasil perhitungan dengan metode Monte Carlo Simulation, menunjukkan bahwa jumlah sampel yang dibutuhkan dalam penelitian ini adalah setidaknya sebanyak 130 responden.

Jumlah partisipan yang setuju untuk berpartisipasi melalui lembar informed consent dalam penelitian ini sebanyak 143 responden, dengan distribusi frekuensi subjek dikategorikan berdasarkan jenis kelamin (62.9\% perempuan; 37.1\% laki-laki), usia (79.7\% dibawah 31 tahun; 20.3\% diatas 31 tahun), pendidikan terakhir (58\% sarjana; 21.7\% SMA/SMK; 11.9\% diploma; 8.4\% magister/profesi), jenis pekerjaan (88.8\% full-time; 11.2\% part-time), dan masa kerja (49\% kurang dari 2 tahun; 34.3\% dalam rentang 2-10 tahun; 16.8\% lebih dari 10 tahun).

\section{Pengukuran}

Pada penelitian ini, variabel work engagement diukur menggunakan alat ukur Utrecht Work Engagement Scale (UWES) yang telah melalui proses translasi kedalam bahasa Indonesia dalam penelitian Kristiana, dkk. (2018) yang terdiri dari 9 aitem dengan 7 pilihan jawaban ( $0=$ "tidak pernah", 6="selalu"), dengan hasil uji validitas yang menunjukkan skor Content Validity Index (CVI) sebesar 0,98 dan hasil uji reliabilitas melalui teknik McDonald's $\omega$ yang menunjukkan koefisien reliabilitas sebesar $\omega=.917$. Kemudian, quality of work life diukur menggunakan skala Quality of Work Life yang disusun oleh Almarshad (2015), dan terdiri dari 30 aitem dengan 5 pilihan jawaban (1="sangat tidak setuju", $5=$ "sangat setuju"), dengan skor CVI sebesar 0.95 dan koefisien reliabilitas yang sangat baik $(\omega=.936)$. Selanjutnya, workplace happiness diukur menggunakan alat ukur Happiness at Work Measurement Scale yang disusun oleh Ramirez-Garcia (2019), dan terdiri dari 11 aitem dengan 7 pilihan jawaban (1="sangat tidak setuju", 7="sangat setuju"), dengan skor CVI sebesar 0.9 dan koefisien reliabilitas yang sangat baik $(\omega=.939)$.

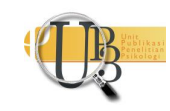


Berdasarkan pemaparan diatas, diketahui bahwa ketiga alat ukur yang digunakan dalam penelitian ini dianggap valid, karena menunjukkan skor Content Validity Index (CVI) diatas 0.8. Selain itu, ketiga alat ukur yang digunakan dalam penelitian ini juga dianggap memiliki reliabilitas tinggi, karena masingmasing alat ukur menunjukkan koefisien reliabilitas mendekati angka 1.

\section{Analisis Data}

Teknik analisis data yang digunakan untuk menguji hipotesis dalam penelitian ini adalah melalui uji bootstrapped mediation regression tanpa melakukan uji asumsi klasik. Selanjutnya, peneliti melakukan analisis jalur (path analysis) yang bertujuan untuk mengetahui hubungan sebab-akibat secara langsung maupun tidak langsung yang terjadi pada model mediasi dalam penelitian ini. Melalui analisis jalur, nantinya akan didapatkan jalur yang paling tepat dari suatu variabel bebas menuju variabel terikat yang terakhir. Pengolahan data dalam penelitian ini seluruhnya menggunakan bantuan perangkat Jamovi 1.1.7.0 for Mac OS.

\section{HASIL PENELITIAN}

Hasil analisis deskriptif dalam penelitian ini menunjukkan bahwa partisipan yang memiliki tingkat quality of work life dalam kategori tinggi sebanyak 23 partisipan (16.08\%), dalam kategori sedang sebanyak 99 partisipan (69.23\%), dan pada kategori rendah sebanyak 21 partisipan (14,69\%). Selanjutnya, pada tingkat workplace happiness diketahui bahwa sebanyak 19 partisipan (13.29\%) termasuk dalam kategori tinggi, sebanyak 102 partisipan (71.33\%) termasuk dalam kategori sedang, dan sebanyak 22 partisipan (15.38\%) termasuk dalam kategori rendah. Kemudian, pada tingkat work engagement menunjukkan bahwa sebanyak 21 partisipan (14.69\%) termasuk dalam kategori tinggi, sebanyak 99 partisipan (69.23\%) termasuk dalam kategori sedang, dan sebanyak 23 partisipan $(16.08 \%)$ termasuk dalam kategori rendah.

Berdasarkan hasil analisis mediasi melalui uji bootstrapped regression, diketahui bahwa quality of work life berpengaruh secara langsung terhadap work engagement $\left(B=0,112 \mathrm{CI}_{95}[0,0041 ; 0,217], S E=0,0554\right.$, $p=0,043$ ) dengan proporsi yang lebih besar apabila efek tersebut dimediasi oleh workplace happiness $\left(B=0,318 \mathrm{CI}_{95}[0,2058 ; 0,420], S E=0,0527, p<0,001\right)$. Secara umum, kedua prediktor dalam penelitian ini yaitu quality of work life dan workplace happiness memiliki pengaruh terhadap work engagement $\left(B=0,430 \mathrm{CI}_{95}[0,3523 ; 0,506], S E=0,0403, p<0,001\right)$. Selain itu, hasil analisis diatas menunjukkan bahwa rentang kepercayaan (confidence interval) tidak mencakup nilai $0\left(B=0,318 \mathrm{CI}_{95}[0,2058 ; 0,420]\right.$, $S E=0,0527, p<0,001$ ), sehingga dapat diketahui bahwa terdapat efek tidak langsung yang signifikan dan terjadi efek mediasi pada kualitas kehidupan kerja terhadap keterikatan kerja melalui kebahagiaan di tempat kerja. Kemudian, diketahui bahwa workplace happiness dapat menjelaskan sekitar 73,9\% dari total effect namun masih terdapat efek langsung yang signifikan, sehingga hasil pada penelitian ini tergolong dalam partial mediation. Hal ini menunjukkan bahwa terdapat adanya peran mediasi parsial dari workplace happiness (variabel Z) yang secara tidak langsung mengendalikan pengaruh quality of work life (variabel X) terhadap work engagement (variabel Y).

Berdasarkan hasil analisis koefisien jalur, diketahui bahwa pada jalur a $(\mathrm{X}-\mathrm{Z})$ menunjukkan variabel quality of work life berkorelasi positif dan berpengaruh secara signifikan $\left(B=0,581 \mathrm{CI}_{95}[0,5100 ; 0,650]\right.$, $S E=0,0355, p<0,001)$ terhadap variabel workplace happiness. Kemudian, pada jalur b (Z-Y) menunjukkan variabel workplace happiness memiliki korelasi yang positif dan berpengaruh secara

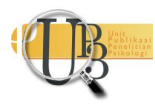


signifikan $\left(B=0,547 \mathrm{CI}_{95}[0,3602 ; 0,686], S E=0,0801, p<0,001\right)$ terhadap variabel work engagement. Selanjutnya, pada jalur c (X-Y) juga menunjukkan variabel quality of work life berkorelasi positif dan berpengaruh secara signifikan $\left(B=0,112 \mathrm{CI}_{95}[0,0041 ; 0,217], S E=0,0554, p=0,043\right)$ terhadap variabel work engagement.

\section{DISKUSI}

Penelitian ini bertujuan untuk mengetahui dan menganalisis pengaruh quality of work life terhadap tingkat work engagement yang dimediasi oleh workplace happiness pada pekerja yang bekerja dari kantor (work from office) di masa pandemi COVID-19. Berdasarkan analisis data yang telah dilakukan dalam penelitian ini, diketahui bahwa kualitas kehidupan kerja (quality of work life) memiliki korelasi positif dan berpengaruh secara signifikan $(p=0.043)$ terhadap keterikatan kerja (work engagement). Artinya, ketika tingkat kualitas kehidupan kerja yang dirasakan oleh pekerja semakin tinggi, maka tingkat keterikatan kerja yang dimiliki juga akan semakin tinggi. Hasil penelitian ini selaras dengan penelitian Sahni (2019) yang menjelaskan bahwa peningkatan kualitas kehidupan kerja akan meningkatkan tingkat keterikatan kerja yang dimiliki oleh para pekerja. Selain itu, dalam Avianto, dkk. (2019) turut menyebutkan bahwa kualitas kehidupan kerja memiliki pengaruh dalam proses penciptaan dan penguatan tingkat keterikatan kerja.

Selanjutnya, diketahui bahwa kualitas kehidupan kerja (quality of work life) memiliki korelasi positif dan berpengaruh secara signifikan $(p<0,001)$ terhadap kebahagiaan di tempat kerja (workplace happiness). Artinya, ketika tingkat kualitas kehidupan kerja yang dimiliki oleh pekerja semakin tinggi, maka tingkat kebahagiaan di tempat kerja yang dirasakan juga akan meningkat. Hasil penelitian ini selaras dengan penelitian Sahni (2019) yang membuktikan bahwa semakin baik kualitas kehidupan kerja maka semakin bertambah pula kebahagiaan yang dirasakan oleh para pekerja di tempat kerja. Selain itu, Wallapa (dalam Butt, dkk., 2019) juga menjelaskan bahwa kualitas kehidupan kerja dianggap sebagai hal yang penting dalam memelihara kebahagiaan yang dirasakan oleh pekerja.

Kemudian, diketahui bahwa kebahagiaan di tempat kerja (workplace happiness) memiliki korelasi positif dan berpengaruh secara signifikan $(p<0,001)$ terhadap keterikatan kerja (work engagement). Artinya, ketika tingkat kebahagiaan di tempat kerja yang dirasakan oleh pekerja semakin tinggi, maka tingkat keterikatan kerja yang dimiliki juga akan semakin tinggi. Hasil penelitian ini selaras dengan penelitian Claypool (2017) yang membuktikan bahwa terdapat hubungan yang signifikan dan positif antara kebahagiaan di tempat kerja dengan keterikatan kerja.

Berdasarkan hasil analisis efek mediasi pada penelitian ini, diketahui kualitas kehidupan kerja (quality of work life $)$ memiliki korelasi positif dan berpengaruh secara signifikan $(p<0,001)$ terhadap keterikatan kerja (work engagement) ketika dimediasi oleh kebahagiaan di tempat kerja (workplace happiness). Efek mediasi dari kebahagiaan di tempat kerja (workplace happiness) dalam menjelaskan pengaruh kualitas kehidupan kerja (quality of work life) terhadap keterikatan kerja (work engagement) tergolong dalam partial mediation. Artinya, kualitas kehidupan kerja memiliki pengaruh yang signifikan secara langsung maupun tidak langsung terhadap keterikatan kerja melalui kebahagiaan di tempat kerja sebagai variabel mediator. Apabila kualitas kehidupan kerja yang dimiliki pekerja tinggi, maka dapat meningkatkan kebahagiaan di tempat kerja, yang kemudian juga dapat meningkatkan tingkat keterikatan kerja.

Jika ditinjau pada setting situasi pandemi COVID-19, diketahui bahwa rutinitas bekerja dari kantor (work from office) selama masa pandemi COVID-19 akan cenderung tidak menyebabkan perubahan terhadap kebahagiaan dan keterikatan kerja ketika kualitas kehidupan kerja tetap diperhatikan oleh

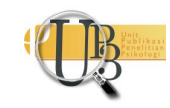


organisasi, seperti mendukung pekerja untuk berkembang, menciptakan lingkungan kerja yang aman dan terbuka, meningkatkan komunikasi agar keinginan pekerja dan organisasi dapat tersampaikan, menciptakan kebijakan yang jelas untuk menghindari stress pada pekerja, memberikan umpan balik dan penilaian kinerja, menciptakan kenyamanan kondisi lingkungan kerja, serta memberikan kesempatan pada pekerja untuk melakukan pekerjaannya dengan baik (Chanana \& Sangeeta, 2020; Dewi, dkk., 2020).

\section{SIMPULAN}

Berdasarkan hasil yang ditunjukkan dalam penelitian ini, maka dapat disimpulkan bahwa terdapat pengaruh quality of work life terhadap tingkat work engagement yang dimediasi oleh workplace happiness pada pekerja yang bekerja dari kantor (work from office) di masa pandemi COVID-19, dengan arah korelasi positif dan efek mediasi berperan secara parsial.

Saran untuk penelitian selanjutnya diharapkan dapat mempertimbangkan untuk melakukan spesifikasi pada kriteria subjek penelitian, karena diketahui biographical characteristics seperti usia, jenis kelamin, dan masa kerja dapat mempengaruhi perilaku berorganisasi pada karyawan, termasuk keterikatan kerja (Sipayung, 2012). Selain itu, penelitian selanjutnya dapat meneliti dan menjelaskan dinamika dari faktor lain diluar variabel yang diteliti, yang sekiranya dapat memprediksi tingkat keterikatan kerja, seperti management of human resources dan perceived of organizational support (Avianto, dkk., 2019).

Selain itu, organisasi diharapkan dapat menciptakan budaya organisasi yang komunikatif dan suportif, meningkatkan dukungan organisasi, mendorong kepercayaan pekerja melalui adanya transparansi kebijakan, memelihara konsistensi pemimpin dalam melakukan mentoring terhadap pekerja, memberikan umpan balik dan penilaian kinerja, serta menciptakan kenyamanan lingkungan kerja untuk memelihara kebahagiaan dan keterikatan kerja pada masa pandemi COVID-19 (Kewalramani, 2020; Dewi, dkk., 2020).

\section{UCAPAN TERIMAKASIH}

Terima kasih diucapkan kepada Tuhan Yang Maha Esa, keluarga, teman-teman, dan seluruh pihak yang telah membantu dan mendukung penulis hingga mampu untuk mencapai titik ini. Terima kasih atas segalanya, semoga senantiasa dikelilingi oleh kebahagiaan dan kebaikan.

\section{DEKLARASI POTENSI TERJADINYA KONFLIK KEPENTINGAN}

Chansa Visyahra Nugraha dan Fendy Suhariadi tidak bekerja, menjadi konsultan, memiliki saham, atau menerima dana dari perusahaan atau organisasi manapun yang mungkin akan mengambil untung dari diterbitkannya naskah ini.

\section{PUSTAKA ACUAN}

Alexander. (2019). Employee Engagement VS Happiness at Work - What Should Companies Focus On? Retrieved October 20, 2020, from Positive Sharing.

Almarshad, S. O. (2015). A Measurement Scale for Evaluating Quality Of Work Life: Conceptualization and Empirical Validation. Trends in Applied Sciences Research, 10 (3), 143-156. 
Avianto, B., Derriawan, \& Tabroni. (2019, December). Pengaruh Praktik Manajemen Sumber Daya Manusia dan Persepsi Dukungan Organisasi terhadap Keterikatan Karyawan dengan Kualitas Kehidupan Kerja sebagai Variabel Intervening. Jurnal Ekonomi Bisnis dan Manajemen, 4(1), 140164.

Bakker, A. B., \& Albrecht, S. (2018). Work Engagement: Current Trends. Career Development International, 23(1), 4-11.

Bungin, B. (2011). Metodologi Penelitian Kualitatif. Jakarta: PT. Raja Grafindo Persada.

Butt, R. S., Altaf, S., Chohan, I. M., \& Ashraf, S. F. (2019). Analyzing the Role of Quality of Work Life and Happiness at Work on Employees Job Satisfaction with The Moderation of Job Stress, Empirical Research of Jiangsu University. International Journal of Scientific \& Technology Research, 8(10), 1905-1915.

Chanana, N. \&. (2020). Employee Engagement Practices during COVID-19 Lockdown. 1-8.

Claypool, K. K. (2017). Organizational Success: How the Presence of Happiness in the Workplace affects Employee Engagement that Leads to Organizational Success. Pepperdine University, Graduate School of Education and Psychology. United States: ProQuest.

Coronavirus Knowledge Portal. (2020). Retrieved October 19, 2020, from HRO Today.

Dewi, R. P., Utami, N. I., \& Ahmad, J. (2020). Quality of Work Life dan Work Engagement pada Dosen Perguruan Tinggi Swasta di Yogyakarta. Jurnal Psikologi, 13 (1), 15-25.

Djamba, Y. K., \& Neuman, W. L. (2002). Social Research Methods: Qualitative and Quantitative Approaches. Teaching Sociology, 380-381.

Fadini, B. (2021). Employee Engagement in HR: Why it Still Matters in our Remote Digital World. Retrieved April 17, 2021.

Fisher, C. D. (2010). Happiness at Work. International Journal of Management Reviews, 12 (4), 384-412.

Harter. (2020). Employee Engagement Continues Historic Rise Amid Coronavirus. Retrieved February 6, 2020, from Gallup.

Harter, J. K., Schmidt, F. L., \& Hayes, T. L. (2002). Business-unit-level Relationship between Employee Satisfaction, Employee Engagement, and Business Outcomes: A mete-analysis. Journal of Applied Psychology, 87(2), 268-279.

Hempfling, M. S. (2015). Happiness, Work Engagement, and Perception of Organizational Support of Student Affairs Professionals. Dissertation, The Patton College of Education of Ohio University.

Kewalramani, A. R. (2020). What has COVID-19 Taught Us about Employee Engagement? Retrieved February 15, 2020, from Deloitte. 
Kniffin, K. M. (2020). COVID-19 and the Workplace: Implications, Issues, and Insights for Future Research and Action. Harvard Business School.

Kristiana, I. F. (2018). Analisis Rasch dalam Utrecht Work Engagement Scale-9 (UWES-9) Versi Bahasa Indonesia. Jurnal Psikologi, 17 (2), 204-217.

Kumar, A., \& Kapoor, S. (2020). Employee Engagement amidst COVID-19 Pandemic: A Challenge or Opportunity for Indian Organisations. International Journal of Advanced Science and Technology, 29(9s), 1980-1987.

Marajohan, E. J. (2016). Employee Engagement in Indonesia (Pembahasan Hasil Temuan Gallup Organization).

Muslim, M., Suhariadi, F., \& Damayanti, N. A. (2018). The Performance of Medical Laboratory Technician based on situation Awareness and Psychological Capital with the Work engagement Mediation. Indian Journal of Public Health Research and Development, 9 (1).

Nurendra, A. M., \& Purnamasari, W. (2017). Hubungan antara Kualitas Kehidupan Kerja dan Keterikatan Kerja pada Pekerja Wanita. Indigenous: Jurnal Ilmiah Psikologi, 2(2), 148-154.

Pri, R., \& Zamralita. (2017). Gambaran Work Engagement pada Karyawan di PT. EG (Manufacturing Industry). Jurnal Muara Ilmu Sosial, Humaniora, dan Seni , 1 (2), 295-303.

Ramirez-Garcia, C. D. (2019). Happiness at Work: Measurement Scale Validation. Journal of Business Management, 327-340.

Rotenberg, Z. (2021). The Impact of Employee Engagement on Performance and Results.

Sahni, J. (2019). Quality of Work Life (QWL), Quality of Life (QoL), and Happiness: Exploring the Linkages for Millenial Workforce. Internal Quality Conference, (pp. 815-824).

Sahni, J. (2019). Role of Quality of Work Life in Determining Employee Engagement and Organizational Commitment in Telecom Industry. Intrnational Journal for Quality Research, 13(2), 285-300.

Schaufeli, W. B., \& Bakker, A. B. (2004). Job Demands, Job Resources, and Their Relationship with Burnout and Engagement: A Multi-Sample Study. Journal of Organizational Behavior, 25, 293-315.

Schoemann, A. M. (2017). Determining Power and Sample Size for Simple and Complex Mediation Models. Social Psychology and Personality Science. $X X(X), 1-8$.

Walton, R. (1980). Quality of Work Life Activities: A Research Agenda. Journal Professional Psychology, $11(3)$.

Xanthopoulou, D., Bakker, A. B., Demerouti, E., \& Schaufeli, W. B. (2009). Work Engagement and Financial Returns: A Diary Study on the Role of Job and Personal Resources. Journal of Occupational and Orgaizational Psychology, 82(1), 183-200.

Zhao, X. Y., \& Sun, J. (2010). A Literature Review on Employee Engagement. Journal of Beijing University of Posts and Telecommunications, 12(5), 93-98. 